\title{
A Review of Characteristics of Landfilled Municipal Solid Waste in Several Countries: Physical Composition, Unit Weight, and Permeability Coefficient
}

\author{
Rong Yang ${ }^{1}$, Zengguang Xu ${ }^{1 *}$, Junrui Chai ${ }^{1,2 * *}$ \\ ${ }^{1}$ State Key Laboratory of Eco-hydraulics in Northwest Arid Region of China, \\ $\mathrm{Xi}^{\prime}$ an University of Technology, Shaanxi, China \\ ${ }^{2}$ School of Civil Engineering, Xijing University, Xi'an, China
}

Received: 4 October 2017

Accepted: 8 December 2017

\begin{abstract}
The characteristics of landfilled municipal solid waste have great influence on the design, operation, and management of landfills, affecting settlement, slope stability, and leachate/gas well integrity. Through analysis and study we observed that the landfill method is widely used to dispose of municipal solid waste (MSW), especially in developing countries. The research results of MSW landfill properties are different due to waste inhomogeneity. In this paper, MSW physical composition, unit weight, and permeability coefficient of landfills in several countries were reviewed and discussed. Landfilled MSW has strong regional and temporal characteristics. Landfilled MSW of developing countries has high organic content ranges from $75.00 \%$ to $97.15 \%$. The organic contents in landfills of most developed regions are relatively small. The unit weight ranged from $4.9-17.8 \mathrm{kN} / \mathrm{m}^{3}$ and the permeability coefficient ranged from $3.5 \times 10^{-2} \mathrm{~cm} / \mathrm{sec}$ to $5.0 \times 10^{-8} \mathrm{~cm} / \mathrm{sec}$ within $60 \mathrm{~m}$. In the process of waste degradation, MSW physical composition, unit weight, and permeability coefficient are changed. Waste classification improves the recovery and utilization of landfill and reduces the amount of waste, which affects the characteristics of landfilled MSW. Thus, strengthening waste classification, recycling, and recovery of MSW is significant and meaningful for construction, operation, and management of landfills.
\end{abstract}

Keywords: municipal solid waste, MSW disposal method, physical composition, unit weight, permeability coefficient

*e-mail: xuzengguang@xaut.edu.cn

** e-mail: jrchai@xaut.edu.cn 


\section{Introduction}

Municipal solid waste (MSW) mainly includes food and fruit, wood, paper, textiles, plastics, and dust. MSW landfills are made up of MSW formed by layer compaction. With the improvement of economic levels and the increase in urban populations, the production of MSW has increased sharply. In the middle of the 18th century, only $3 \%$ of the world's population lived in the city; in 1950, the proportion of the urban population accounted for $29 \%$; in 1985 , the population increased up to $41 \%$; and in $2025,60 \%$ of the world's population will live in or around cities. According to statistics, the domestic waste production of China increased at a rate of about $9 \%$ per year. Waste production increased from 52 million tons in 1986 to 166 million tons in 1996. In the first 50 years of the 21st century, the sustainable urban development in China faced a grim challenge in which the growth rate of MSW production reached peak with the increase of China's population growth and urbanization level [1-2].

\section{MSW Disposal Methods}

The disposal techniques of MSW mainly include 3 kinds of methods: incineration, composting, and landfilling [3-5]. Incineration is often used in developed countries. It has high efficiency in waste disposal. The heat generated by burning can be used to produce electricity and requires a small land area. However, the method presents some difficulties such as large investment and high technical content, and the unclassified collection of waste is a problem for developing countries. Although composting is a good reductive and regenerative MSW disposal method, the high cost, high technical content, and collection of waste is not classified - especially in developing countries. The sanitary landfill method is the most popular waste treatment technology in the world because of its high handing capacity, decreased investment, and low technical content. However, it occupies a large land area and is not effective in reducing waste. Recycling is also a method for disposing of MSW.
Recycling of MSW at the source can reduce the amount of MSW directly disposed by half [6].

Fig. 1 presents the MSW disposal methods in different countries or cities. Others include recycling, untreated, and unclear methods.

Developing countries such as India and China use landfill technology to deal with MSW, as shown in Fig. 1. The landfill method accounted for as much as $91 \%$, and incineration is rarely used by these countries. In India, open dumping of the landfill method is mainly used to dispose of MSW, and it easily caused serious environmental and economic problems [14-20]. In addition to the use of the landfill method, incineration also occupied a very important position in developed countries. The use of incineration is a good choice, especially in Japan, given its small land area requirement. There are some slightly developed countries or cities, such as Denmark, Singapore, and Macao, that use the incineration method. Although the use of incineration technology to deal with $\mathrm{MSW}$ is up to $83 \%$, landfill technology is less used. Through analysis, one reason is their small land areas. Nepal is primarily an agricultural country and mainly uses the composting method to deal with MSW. But of course there are exceptions. Waste disposal policy is still an important factor. For instance, Germany was disposing of $69 \%$ MSW in landfills in 1993, but this method was banned in 2005.

Based on the above data and analysis, the choice for the main MSW disposal method for a country or a city is mainly based on waste management strategy, economic development, land area, population, and waste classification. Moreover, the main economic source of a country or a city and the technology used for MSW disposal have certain influence on the disposal method.

Landfill technology can deal with almost all the waste in a city and the cost is low relative to other methods [21]. The method was widely used by various countries to deal with MSW, and it was the major disposal method for a long time [22-23]. With the rapid increase of urban population and the rapid development of industry, landfill as the main MSW disposal method gradually tended to

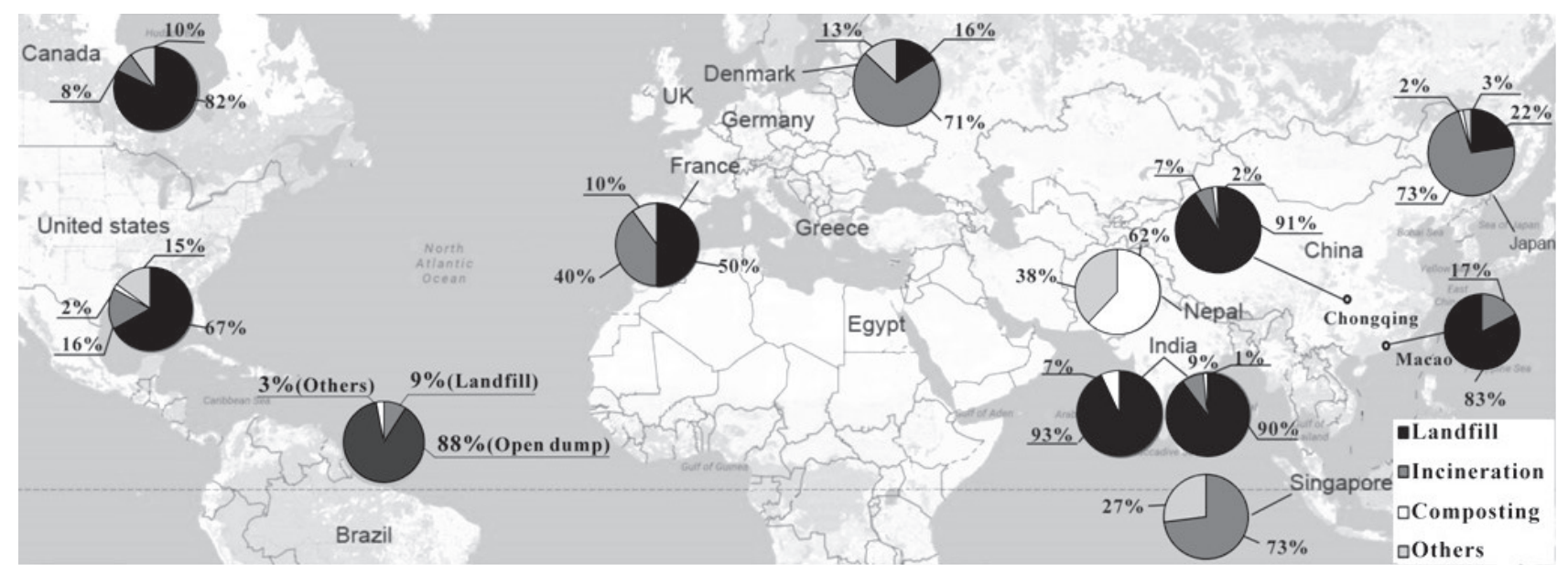

Fig.1. Statistics of MSW disposal methods [7-13]. 
Table 1. Statistics of failure in various landfills.

\begin{tabular}{|c|l|c|c|c|}
\hline MSW Landfill & Year & $\begin{array}{c}\text { Accident } \\
\text { description }\end{array}$ & Consequences & Reasons \\
\hline $\begin{array}{c}\text { Landfill in Bandung, } \\
\text { Indonesia [24] }\end{array}$ & 2005 & $\begin{array}{c}\text { Waste pile } \\
\text { collapse }\end{array}$ & $\begin{array}{c}2.7 \text { million } \mathrm{m}^{3} \text { of solid waste went down and 147 } \\
\text { people were killed }\end{array}$ & High pore pressures \\
\hline $\begin{array}{c}\text { Chongqing Shapingba } \\
\text { Landfill, China [25] }\end{array}$ & 2002 & Landslide & $\begin{array}{c}\text { About } 0.4 \text { million } \mathrm{m}^{3} \text { of solid waste slumped, } \\
\text { the 3-layer dormitory of gravel factory mountain } \\
\text { was swallowed and 10 people were killed }\end{array}$ & $\begin{array}{c}\text { The composition of waste } \\
\text { and heavy rain }\end{array}$ \\
\hline $\begin{array}{c}\text { Payatas Landfill, } \\
\text { Philippines [26] }\end{array}$ & 2000 & Landslide & $\begin{array}{c}\text { About 278 people were killed and more than } \\
100 \text { people went missing }\end{array}$ & $\begin{array}{c}\text { Uncompacted significant } \\
\text { want continuous } \\
\text { heavy rain }\end{array}$ \\
\hline $\begin{array}{c}\text { Dona Juana Landfill, } \\
\text { Columbia [27] }\end{array}$ & 1997 & $\begin{array}{c}\text { Waste slope } \\
\text { failure }\end{array}$ & $\begin{array}{c}\text { About } 1.2 \text { million } \mathrm{m}^{3} \text { of solid waste with a large } \\
\text { amount of leachate rapidly slumped in 20 min, } \\
\text { rushed out for 1.5 km, and caused serious } \\
\text { environmental pollution }\end{array}$ & $\begin{array}{c}\text { High leachate level due to } \\
\text { leachate recirculation }\end{array}$ \\
\hline $\begin{array}{c}\text { The former Yugoslavia, } \\
\text { Sarajevo MSW } \\
\text { Landfill [28] }\end{array}$ & 1977 & $\begin{array}{c}\text { Waste pile } \\
\text { collapse }\end{array}$ & $\begin{array}{c}\text { 2 bridges, 5 houses, and 2 small rivers were } \\
\text { completely submerged }\end{array}$ & \\
\hline
\end{tabular}

develop in high piles and large capacities. Thus, landfill stabilization problem pose a serious threat to people's life and property safety [2].

\section{How Important and Urgent is it to Study Landfilled MSW Characteristics?}

Physical composition, unit weight, and permeability coefficient of MSW are important parameters affecting the stability of a landfill. Several experts have researched these aspects by model test or numerical analysis. So far, no uniform or more mature understanding in engineering characteristic parameters has been drawn all over the world, owing to the complexity of physical composition and degradation. Table 1 shows the statistics of the failure of landfills.

Based on the investigation and research of the above literature, several causes that led to landfill failures were the following:

1) Excessively high leachate levels occurring in the landfill due to heavy rain, leachate recirculation, or more waste water content, which caused landslides. The leachate level of MSW landfill was influenced by rain, MSW physical composition, compaction, permeability coefficient, drainage systems, and so on.

2) The waste composition and compaction degree had direct influence on the strength characteristics and permeability coefficients of the landfill, which led to the destruction of the landfill.

3) Improper design or mismanagement led to the destruction of the landfill. As a result, the composition, unit weight, and permeability coefficient of waste piles were essential for landfill safety. Research on the engineering characteristics of the landfill has not formed a unified understanding due to its anisotropy and complexity. Thus, the engineering characteristics of MSW are an urgent issue worthy of further study. With the increase in urban populations and the improvement in quality of life, various landfills are much closer to the saturation point at present. The landfills develop toward high pile bodies and large capacities. In the case of landslides directly threatening lives, property safety, and the surrounding environment, the slope stability of a landfill is an important problem. The engineering properties of MSW directly affect the distribution of leachate and slope stability in a landfill. Because engineering properties of MSW are closely related to the physical compositions, the physical compositions of MSW are analyzed, and the unit weight and permeability coefficient are studied in this paper.

\section{Results and Discussion}

\section{Physical Composition of Landfilled MSW}

Landfilled MSW has a complicated physical composition, but it is mainly composed of organic and inorganic substances. Organics mainly include food, wood, paper, textiles, plastics, and rubber, etc. Inorganics include metal, glass, tiles, and ash, etc. [29]. MSW compositions differ by times and regions [30-31]. The analysis of landfilled MSW physical compositions can provide the basis for the design of a landfill. To a certain degree, MSW physical compositions can represent the landfilled MSW physical compositions because of an ineffective waste recycling system and the only disposal method of MSW in many countries. Following are analyses of landfilled MSW compositions in spatiotemporal distributions in several countries.

\section{MSW Compositions in Spatial Distribution}

The MSW compositions of landfills in several countries are shown in Tables 2 and 3. These countries or landfills are shown in Fig. 2. 
Table 2. MSW compositions in spatial distribution (percentage of wet mass).

\begin{tabular}{|c|c|c|c|c|c|c|c|c|c|c|}
\hline Locations & Year & Food & Wood & Textiles & Paper & Plastics & Organics & Metal & Glass & Ash and others \\
\hline Egypt [29] & 2016 & \multicolumn{3}{|c|}{56.00} & 10.00 & 13.00 & $\mathbf{7 9 . 0 0}$ & 2.00 & 4.00 & 15.00 \\
\hline Jordan [32-33] & 2015 & \multicolumn{2}{|c|}{52.70} & 10.22 & 9.00 & 12.85 & $\mathbf{8 4 . 7 7}$ & 4.82 & 1.25 & 9.16 \\
\hline China [34] & 2015 & 55.86 & 2.94 & 3.16 & 8.52 & 11.15 & $\mathbf{8 1 . 6 3}$ & \multicolumn{3}{|c|}{18.37} \\
\hline Canada [35] & 2012 & 27.00 & 2.00 & 2.00 & 26.00 & 8.00 & $\mathbf{6 5 . 0 0}$ & \multicolumn{3}{|c|}{35.00} \\
\hline Chihuahua, Mexico [36] & 2009 & \multicolumn{3}{|c|}{45.00} & 17.00 & 13.00 & $\mathbf{7 5 . 0 0}$ & 3.00 & 5.00 & 17.00 \\
\hline Beijing, China [37] & 2006 & 63.39 & 1.78 & 2.46 & 11.07 & 12.70 & $\mathbf{9 1 . 4 0}$ & \multicolumn{2}{|c|}{2.73} & 5.87 \\
\hline Philippines [38] & 2006 & \multicolumn{3}{|c|}{59.10} & 7.40 & 10.50 & $\mathbf{7 7 . 0 0}$ & 1.30 & 1.70 & 20.00 \\
\hline Grete Island, Greece [39] & 2006 & 39.15 & \multicolumn{2}{|c|}{5.24} & 19.94 & 16.85 & $\mathbf{8 1 . 1 8}$ & 3.51 & 5.33 & 9.98 \\
\hline Chongqing, China [8] & 2001 & 59.20 & 4.20 & 6.10 & 10.10 & 15.70 & $\mathbf{9 5 . 3 0}$ & 1.10 & 3.40 & 0.20 \\
\hline United Kingdom [40] & 2000 & 25.00 & 0.00 & 3.00 & 29.00 & 7.00 & $\mathbf{6 4 . 0 0}$ & 8.00 & 10.00 & 18.00 \\
\hline
\end{tabular}

Table 3. Landfilled MSW compositions in spatial distribution (percentage of wet mass).

\begin{tabular}{|c|c|c|c|c|c|c|c|}
\hline Landfill & Year & $\begin{array}{c}\text { Food and } \\
\text { wood }\end{array}$ & $\begin{array}{c}\text { Paper and } \\
\text { textiles }\end{array}$ & Plastics & Organics & Metal & $\begin{array}{c}\text { Dust and } \\
\text { others }\end{array}$ \\
\hline Xi'an Jiangcungou Landfill, China [41] & 2012 & 53.30 & 16.30 & 14.80 & $\mathbf{8 4 . 4 0}$ & 3.31 & 12.29 \\
\hline Bandeirantes Landfill, Brazil [42] & 2010 & 53.80 & 18.60 & 20.90 & $\mathbf{9 3 . 3 0}$ & 5.60 & 1.10 \\
\hline Suzhou Qizishan Landfill, China [43] & 2007 & 63.49 & 15.07 & 18.59 & $\mathbf{9 7 . 1 5}$ & 0.24 & 2.61 \\
\hline Gokarna Landfill, Nepal [44] & 2003 & 70.00 & 11.50 & 9.50 & $\mathbf{9 1 . 0 0}$ & 0.00 & 9.00 \\
\hline Orchard Hills Landfill, United States [45] & 2009 & 18.60 & 30.40 & 11.00 & $\mathbf{6 0 . 0 0}$ & 4.40 & 35.60 \\
\hline New Jersey Landfill, United States [46] & 2005 & 32.10 & 26.70 & 8.90 & $\mathbf{6 7 . 7 0}$ & 4.00 & 28.30 \\
\hline Spyhill Sanitary Landfill, Canada [47] & 2002 & 29.00 & 28.00 & 8.00 & $\mathbf{6 5 . 0 0}$ & 1.50 & 33.50 \\
\hline
\end{tabular}

Based on statistics, the landfilled MSWs of developing countries have high organic content ranging from $75.00 \%$ to $97.15 \%$. The main components were food with contents of $39.15-63.39 \%$ (Table 2), and food and wood with contents of $53.30-70.00 \%$ (Table 3). The MSW had high water content and could easily degrade and cause more leachate production because of the increased organics. Therefore, the leachate levels of landfills are higher

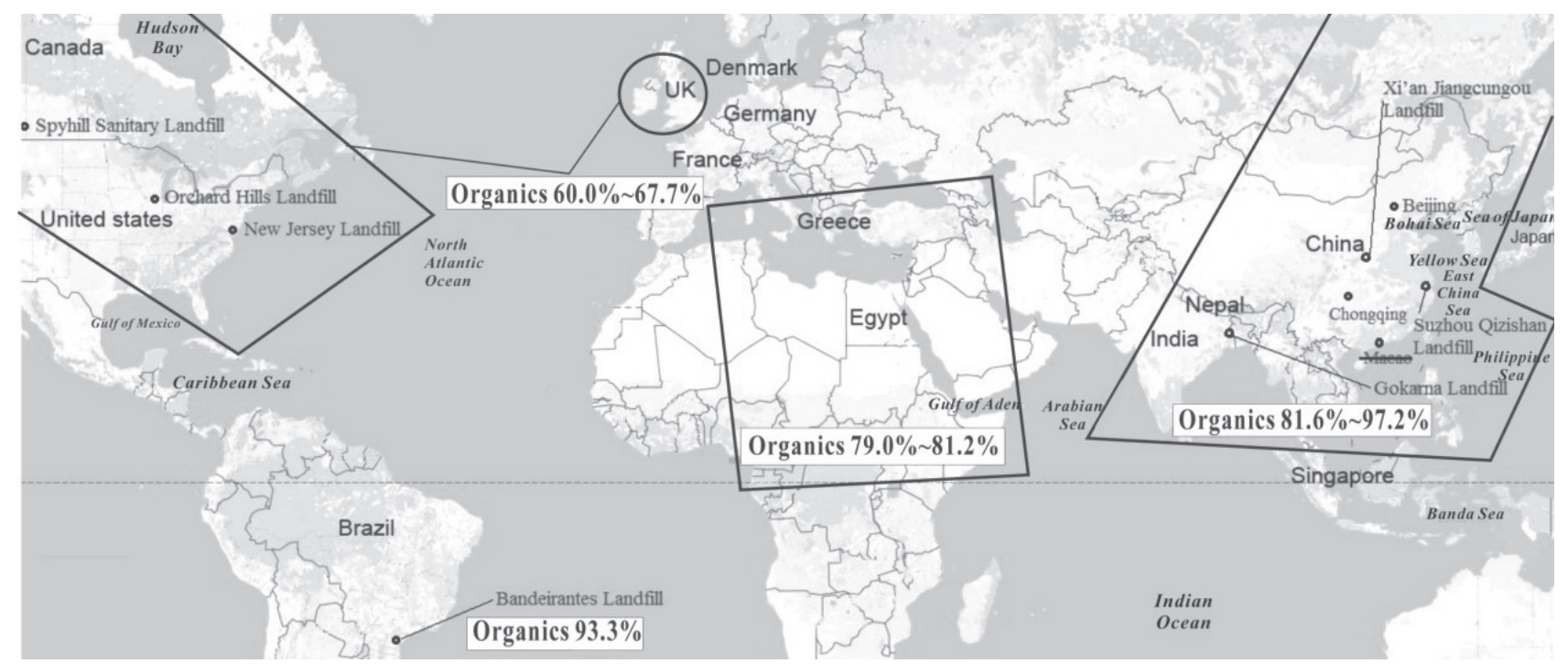

Fig. 2. Organic percentage of landfill waste in several countries. 


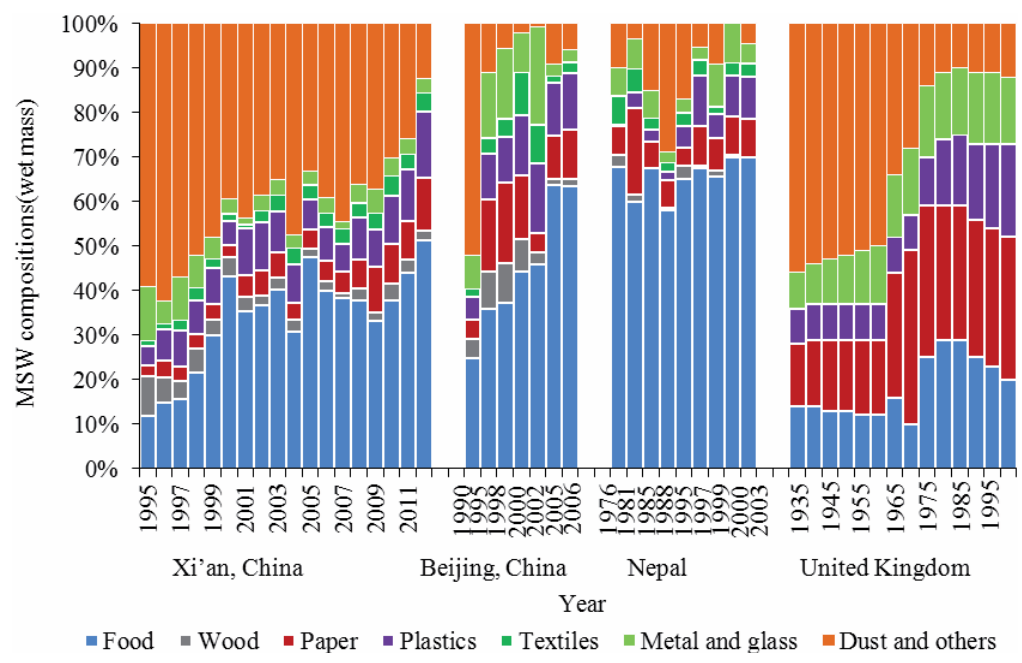

Fig. 3. MSW compositions in temporal distributions [36, 39-40, 43, 47].

and the failure of landfills can occur easily; the organic contents in landfills of developed countries are relatively small on a scale of $60.00-67.70 \%$. The composition content of food and wood ranged from $18.60 \%$ to $32.10 \%$. Compared with developing countries, the inorganics had a big value in landfilled MSW, which is good for the stability of a landfill site. MSW disposal technology is related not only to the level of economic development but also to the country's waste classification system, the degree of recycling, and waste utilization.

\section{MSW Compositions in Temporal Distributions}

As time goes on, the MSW composition contents are constantly changing in the same region. A few selected developing countries and developed countries have been selected to analyze the differences of MSW physical composition changes over time at different development degrees. The MSW average composition contents of four regions are shown in Fig. 3.

Based on the above figure, China's MSW organic composition was on the rise - especially food. On the contrary, inorganic composition was gradually reduced. Moreover, the main components were food, wood, dust, and others, and paper and textiles, plastics, metal and glass account for only small parts. With economic development and population growth, the production of MSW in Beijing increased from 2.96 million tons in 2000 to 6.20 million tons in 2007 [48]. From 1976 to 2003, the MSW composition components of Nepal changed to a low degree. Food occupied the main part with content of about $65 \%$, and inorganic content initially increased and then decreased. From 1960 to 1985, the MSW organic composition components of the United Kingdom increased rapidly, then the organics became stable in 1985-2000. Inorganics were more than $60 \%$ and gradually decreased. Finally, each component's proportions were similar in 2000. In conclusion, food and wood had higher contents in developing Asian countries such as China and Nepal. The United Kingdom belongs to developed European countries, which has similar component proportions.

Given the above, the physical composition of landfilled MSW is affected by MSW management policy, climate, lifestyle, region, times, economic status, and region [4950]. In addition, developed countries or cities have more paper and less food.

\section{Unit Weight of Landfilled MSW \\ Influence Factors of Landfilled MSW Unit Weight}

MSW unit weight is the weight per unit volume of MSW in landfills, and it has great effect on the landfill settlement and slope stability. International scholars

Table 4. Test methods of landfilled MSW unit weight.

\begin{tabular}{|c|c|c|}
\hline \multicolumn{2}{|c|}{ Test methods } & Comments \\
\hline \multirow{2}{*}{$\begin{array}{c}\text { Laboratory } \\
\text { test }\end{array}$} & Average weighting method [41] & Simple, but the average values are rarely used \\
\cline { 2 - 3 } & Measurement of individual component and weights in waste sample & Inaccurate and time-consuming \\
\hline \multirow{3}{*}{ Field test } & Replacement density measurement in boreholes [42] & $\begin{array}{c}\text { Reliable and data obtained for a range of verti- } \\
\text { cal stresses }\end{array}$ \\
\cline { 2 - 3 } & Measurement of waste pile vertical stresses & $\begin{array}{c}\text { Reliable and shows changes related to vertical } \\
\text { stresses }\end{array}$ \\
\hline
\end{tabular}


have done much exploration and research in this area. Landfilled MSW unit weight is significantly affected by the environment. In general, as waste ingredients increase, unit weight varies. In view of landfilled MSW, the more the inorganic content, the greater the unit weight. On the contrary, the more the ingredients such as plastics and paper, the smaller the unit weight [51]. In addition, the main components of the landfilled MSW were worked together by regional climate conditions, living habits, religious beliefs, and many other factors. The compaction degree and degradation degree have significant influence on landfilled MSW unit weight, that is the higher the compaction degree or degradation degree, the greater the landfilled MSW unit weight [52-53].

\section{Test Methods}

The unit weight of waste pile can be obtained by laboratory or field test. Several test methods of unit weight are shown in Table 4.

Laboratory tests are carried out through field sampling, taking the amount of waste samples, measuring their weights and volumes in the laboratory, and then calculating the unit weight. Alternatively, it is determined by the contents and weights of different components in the samples; however, these results are not accurate and are easily influenced by external factors. Field test is the method used to measure landfill unit weight directly in the borehole. The method is accurate, but it has a higher cost and more difficult operation.

\section{Analysis of Landfilled MSW Unit Weight in Several Countries}

MSW unit weight of a landfill is closely related to the buried depth, and the relations have been researched by many scholars [54-55]. Zornberg et al. (1999) [56] determined the MSW unit weight of a southern California landfill by boring test and obtained the unit weight value range of $10-15 \mathrm{kN} / \mathrm{m}^{3}$ with a depth of $8-50 \mathrm{~m}$. In 2005 Zekkos et al. provided the curves of unit weight and depth of 6 U.S. landfills, and gave the recommended profiles of unit weight, which ranged from 5 to $18 \mathrm{kN} / \mathrm{m}^{3}$ with a depth of 0-60 m. According to the data of Cheery Island Landfill, Zekkos et al. (2010) [57] drew the curve with a unit weight value range of $8-12 \mathrm{kN} / \mathrm{m}^{3}$ and a depth of 0-10 m. Meanwhile, they achieved three curves between unit weight and burying depth of the landfill, and the unit weight was growing with the increase of depth in the landfill. Tu and Qian put forward the 3 new curves for MSW landfill of China, which are presented in Fig. 4 [58]. The change of curve was obvious for the low compaction degree, and the unit weight ranged from $5-12 \mathrm{kN} / \mathrm{m}^{3}$ with a depth of 0-60 m. In the typical compaction and high compaction curves, the increasing rate of unit weight gradually slowed down at 20 and $10 \mathrm{~m}$ depths.

Based on the investigation and research of literature, the landfilled MSW unit weight ranged 4.9-12 kN/m 3 and their change tendencies were basically the same in China and the USA. The landfills of China were between low compaction degree and typical compaction degree, while those in the USA were relatively high, such as Tri-Cities Landfill and OII Landfill. The major causes of compaction degree were landfilled MSW physical compositions and compaction technology.

\section{Effect of MSW Unit Weight on Landfill Safety}

MSW unit weight has a large impact in terms of landfill safety. It affects waste settlement deformation and makes a drain bending and deformation of gas wells. Unit weight affects the estimate of the landfill capacity, and affects the design and operation of the landfill [60]. Thus, MSW unit weight is critical to the basis of landfill stability and integrity, waste slope stability, stable liner system, drainage system integrity, leachate/gas well integrity, and the design and operation of the landfill.

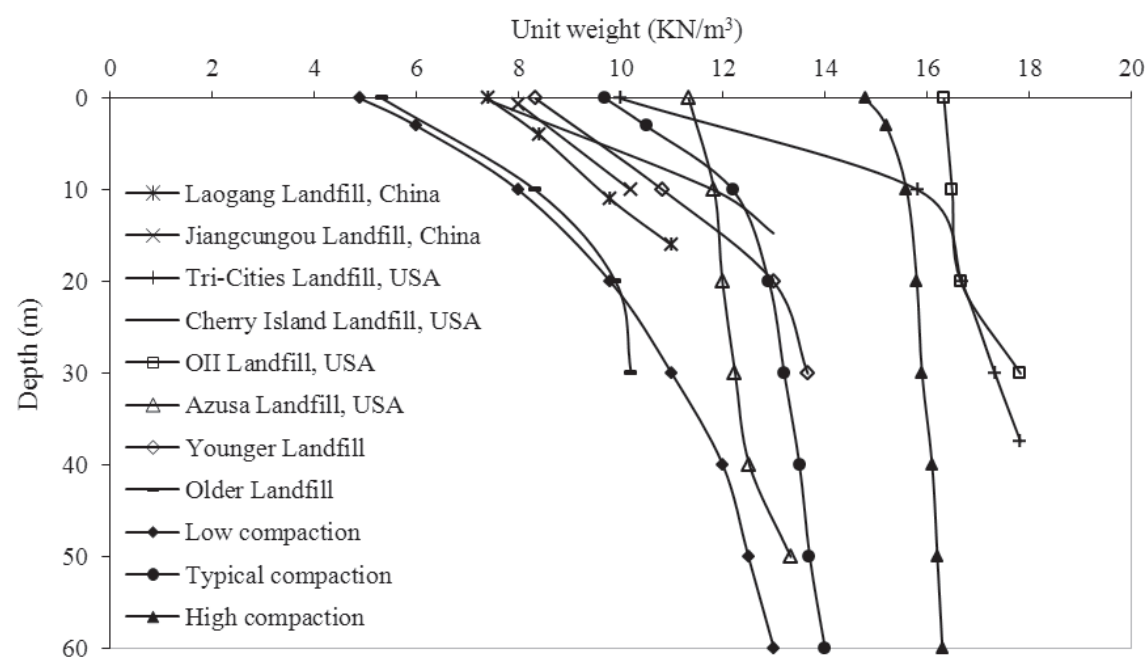

Fig. 4. Comparison of MSW unit weights in different landfills [40, 57-59]. 
Table 5. Test methods of landfilled MSW permeability coefficients.

\begin{tabular}{|c|c|c|}
\hline \multirow{2}{*}{ Test methods } & Comments \\
\hline $\begin{array}{c}\text { Laboratory } \\
\text { test }\end{array}$ & Constant head test [41] & Suitable for large permeability coefficients of shallow waste \\
\cline { 2 - 3 } & Falling head test & Suitable for small permeability coefficients of deep waste or high content dust of waste \\
\hline \multirow{2}{*}{ Field test } & Surface infiltration pit & Suitable for shallow waste \\
\cline { 2 - 3 } & Pumping test [42] & Suitable for whole depth profile \\
\hline
\end{tabular}

\section{Permeability Coefficients of Landfilled MSW}

\section{Influence Factors of Landfilled MSW Permeability Coefficient}

Leachate distribution of a landfill is determined by permeability coefficient, thus affecting landfill stability. MSW compositions have a great influence on the permeability coefficient. The more plastics, glass, and dust content, the smaller the permeability coefficient. In contrast, the more food, wood, paper, and textiles content, the larger the permeability coefficient. MSW compaction degree of landfill directly affects the permeability coefficient. Considering the function of the upper load, the permeability coefficient is small in deep waste. In addition, in the process of waste degradation, the permeability coefficient changes continuously.

\section{Test Methods}

MSW permeability coefficient of a landfill can be obtained by laboratory test or field test. Several test methods are shown in Table 5 .

Measuring the permeability coefficient in the laboratory is simple and inexpensive. However, only the permeability coefficient of the surface-landfilled MSW can be measured during the sampling process. It is difficult to reproduce all the landfill conditions in laboratory tests. Field measurements are normally considered the most reliable approach to estimate the landfilled MSW permeability coefficients.

\section{Analysis of Landfilled MSW Permeability Coefficients in Several Countries}

Permeability coefficient and other indexes were difficult to determine due to the nonuniformity of the MSW

Table 6. MSW permeability coefficients in landfills.

\begin{tabular}{|c|c|c|c|c|}
\hline References & Unit weight $\left(\mathrm{KN} / \mathrm{m}^{3}\right)$ & $\begin{array}{l}\text { Saturated permeability } \\
\text { coefficient }(\mathrm{m} / \mathrm{sec})\end{array}$ & Method & Waste \\
\hline$[63]$ & $7.8-11.8$ & $3.0 \times 10^{-5}-2.9 \times 10^{-6}$ & $\begin{array}{c}\text { Constant head } \\
\text { test }\end{array}$ & Landfill in Korea \\
\hline$[64]$ & / & $1.2 \times 10^{-4}-4.7 \times 10^{-6}$ & $\begin{array}{c}\text { Falling head } \\
\text { test }\end{array}$ & Landfill in Texas, USA \\
\hline$[65]$ & / & $1.0 \times 10^{-4}-1.0 \times 10^{-6}$ & $\begin{array}{l}\text { Falling head } \\
\text { test }\end{array}$ & Landfill in France \\
\hline$[66]$ & $\begin{array}{c}6.4-9.3 \\
\text { (dry unit weight) }\end{array}$ & $1.0 \times 10^{-4}-8.0 \times 10^{-6}$ & $\begin{array}{c}\text { Constant head } \\
\text { test }\end{array}$ & $\begin{array}{l}\text { Home-made } \\
\text { MSW samples }\end{array}$ \\
\hline$[67]$ & $\begin{array}{c}3.1-9.4 \\
4.0-13.0 \\
\text { (dry unit weight) } \\
\end{array}$ & $\begin{array}{l}2.0 \times 10^{-3}-7.8 \times 10^{-7} \\
2.0 \times 10^{-3}-4.9 \times 10^{-7}\end{array}$ & $\begin{array}{c}\text { Steel wall } \\
\text { constant head } \\
\text { test }\end{array}$ & $\begin{array}{l}\text { Landfill in Illinois, } \\
\text { USA }\end{array}$ \\
\hline$[59]$ & $7.2-12.5$ & $6.7 \times 10^{-5}-4.6 \times 10^{-6}$ & $\begin{array}{c}\text { Constant head } \\
\text { test }\end{array}$ & $\begin{array}{l}\text { Laogang landfill } \\
\text { in China } \\
\end{array}$ \\
\hline$[68]$ & $9.8-16.0$ & $1.8 \times 10^{-3}-3.1 \times 10^{-8}$ & $\begin{array}{c}\text { Home-made } \\
\text { devices }\end{array}$ & $\begin{array}{c}\text { Restructuring } \\
\text { waste in China }\end{array}$ \\
\hline [69] & / & $6.3 \times 10^{-6}-1.2 \times 10^{-7}$ & Pumping test & $\begin{array}{c}\text { Fresh Kills Landfill in } \\
\text { New York, USA }\end{array}$ \\
\hline$[70]$ & / & $6.9 \times 10^{-4}-1.2 \times 10^{-4}$ & l & l \\
\hline$[71]$ & $\begin{array}{c}3.56-5.9 \\
4.8-5.9 \\
\text { (Dry unit weight) }\end{array}$ & $\begin{array}{l}1.6 \times 10^{-3}-4.9 \times 10^{-6} \\
1.0 \times 10^{-4}-1.1 \times 10^{-5}\end{array}$ & l & Fresh waste in France \\
\hline$[72]$ & $\begin{array}{l}\text { Not compacted } \\
\geq 300 \mathrm{kPa}\end{array}$ & $1.0 \times 10^{-5}-1.0 \times 10^{-6}$ & I & $\begin{array}{l}\text { Tianziling } \\
\text { landfill in China }\end{array}$ \\
\hline
\end{tabular}




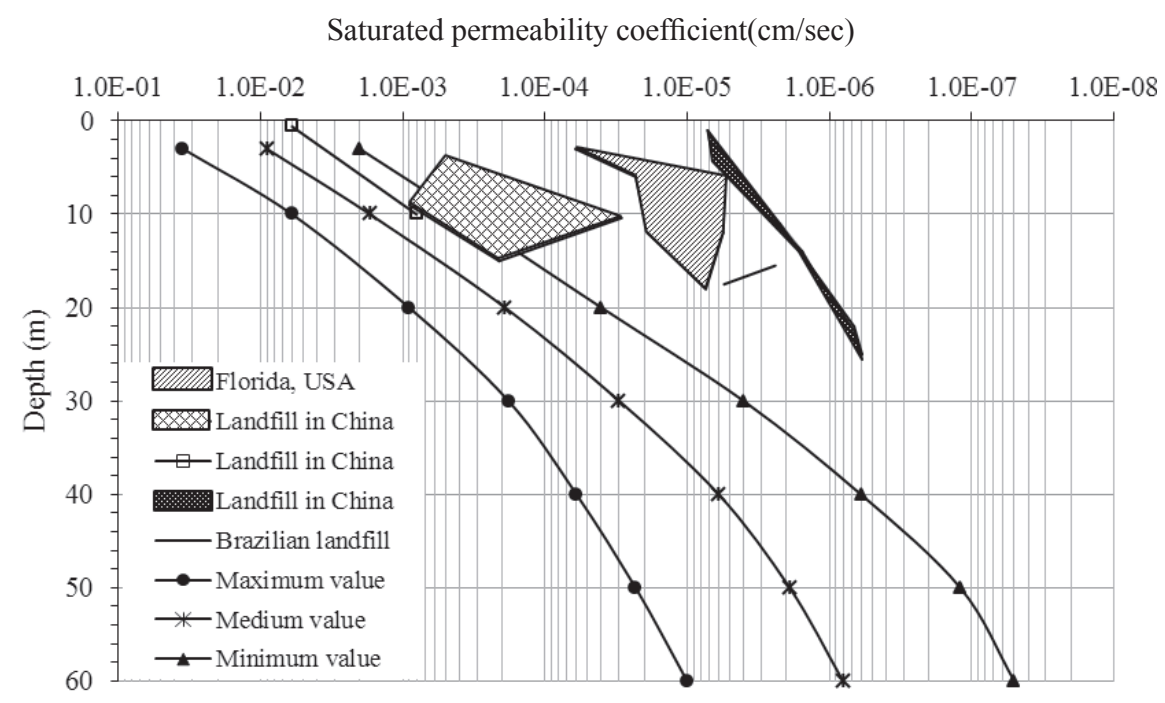

Fig. 5. Comparison of MSW saturated permeability coefficients in several landfills [24, 40-41, 58, 73].

and the limitation of sampling in the landfill. Engineering characteristic parameters, related to landfill safety and stability, were researched and analyzed by Chen and Ke (2005) [61]. The research of permeability coefficient is extremely important to reduce landfill accidents. Landfilled MSW infiltration characteristics directly influence the distribution and level of landfill leachate and greatly influence landfill stability. Gao et al. (2015) [42] counted the variation of permeability coefficient with depth about high kitchen waste content MSW (HKWC MSW) and low kitchen waste content MSW (LKWC MSW). The permeability coefficient of LKWC MSW was larger than that of HKWC MSW at the same depth with a depth of 0-26 m. Li et al. (2014) [62] summarized several factors affecting the permeability coefficient of MSW, including waste density, waste composition, degradation degree, and compaction degree. Two kinds of methods were proposed to adjust the permeability coefficient, namely changing the influence factors and adding inert materials. The research situations of the landfilled MSW saturated permeability coefficients in various countries are shown in Table 6.

According to the survey, the leachate of this landfill reached more than 1,600 tons of every day. Thus, it needs to reduce rainfall infiltration and increase the amount of layer and bottom discharge. According to statistical data, the landfilled MSW permeability coefficient range is very large, at up to $1.0 \times 10^{-8}-2.0 \times 10^{-3} \mathrm{~cm} / \mathrm{sec}$, and the different depth of waste landfill permeability coefficient range is very large. The test method, compaction degree, and composition of the waste is different as well as the permeability coefficient of the landfill of each country.

The relational curves between MSW saturated permeability coefficient and buried depth of landfills are shown in Fig. 5. The range of MSW-saturated permeability coefficients obtained by Jain et al., Wu et al., and Machado et al. was smaller than the minimum value of the standard landfill in China [58, 73-74]. The compaction degree of landfill is high, and the rainfall infiltration is very little. The leachate is mainly produced by high moisture waste and degradation. The permeability coefficients of Jiangcungou Landfill measured by Yang et al. (2016) were between the medium and minimum values, and the compaction degree is relatively low [35]. The leachate is mainly composed of rainfall infiltration, high moisture waste, and degradation.

\section{Effect of MSW Permeability Coefficients on Landfill Safety}

Due to the large permeability coefficients and leachate discharge in a timely manner, the landfill has a high leachate level and landfill slope instability will happen. In addition, permeability coefficient would affect the leachate and gas well integrity, leachate discharge, and leachate/gas collection.

\section{Conclusions}

According to statistics of the methods in dealing with MSW, the influential factors of the MSW disposal methods were analyzed, and the landfill technology was seen as the main means of dealing with MSW in many countries. The incineration method is often used to deal with MSW in developed countries or cities, whereas landfilling is used in developing countries. The differences of landfilled MSW physical composition in several countries were analyzed, and the causes of these differences were proposed. By analyzing the landfill crashes, MSW physical composition, unit weight, and permeability coefficient of the landfill were important factors affecting landfill safety. Finally, the research situation of landfilled MSW physical composition, unit weight, and permeability coefficient were reviewed, and their relationships were analyzed. The following can be concluded: 
1) Similar physical compositions emerged in developing countries. Organic matter content was more (as high as $97.15 \%$ ) and the food as the main ingredients increased over time. The physical compositions of most developed regions were similar. Organic matter content was about $67.7 \%$, and the inorganics had a high value in landfilled MSW compared with developing countries.

2) The measurement methods of MSW unit weight and permeability coefficient were given, and the curves between these 2 parameters and depth were drawn. Within $60 \mathrm{~m}$, the unit weight ranged from 4.9-17.8 $\mathrm{kN} / \mathrm{m}^{3}$ and the permeability coefficient ranged from $3.5 \times 10^{-2} \mathrm{~cm} / \mathrm{sec}$ to $5.0 \times 10^{-8} \mathrm{~cm} / \mathrm{sec}$.

3) In the process of waste degradation, with increasing buried depth, the organic content decreased gradually and waste residue (waste leftovers after degradation) increased. MSW permeability coefficient of landfill decreased and unit weight increased as buried depth increased. But when the buried depth came to a certain value, the values of organic content, unit weight, and permeability coefficient have little change. In general, landfilled MSW has strong regional and temporal characteristics about the physical composition, unit weight, and permeability coefficient.

The view presented in this paper is that classification improves the recovery and utilization of a landfill and reduces the amount of MSW. At the same time the physical composition, unit weight, and permeability coefficients of landfilled MSW change and affect the stability of the landfill slope. As landfilled MSW composition has great influence in construction, operation, and management of landfills, the recycling and recovery of MSW in a previous step of final disposal is strongly recommended.

\section{Acknowledgements}

This study was financially supported by the National Natural Science Foundation of China (51679193 and 51679197) and the Special Funds for the Natural Science Foundation of Shaanxi Province (2017JZ013).

\section{References}

1. HUANG C.Y., LEE C.C., LI F.C., MA Y.P., JENNY SU, H.J. The seasonal distribution of bioaerosols in municipal landfill site: a 3-yr study. Atmospheric Environment, 36 (27), 4385, 2002.

2. CHEN X., GENG Y., FUJITA T. An overview of municipal solid waste management in China. Waste Management, 30 (4), 716, 2010.

3. KRISTINA O.Z., METTE A.M. Understanding the role of waste prevention in local waste management: A literature review. Waste Management and Research, 34 (10), 980, 2016.

4. JIANG J.G., LOU Z.Y., SIIO H., DUO J., LI Z. Technology selection for MSW treatment in Altiplano areas using
FMDM. Waste Management and Research, 27 (7), 634, 2009.

5. US ENVIRONMENTAL PROTECTION AGENCY (EPA). Municipal Solid Waste Generation, Recycling, and Disposal in the US for 2011. Washington, DC, USA: EPA; 2011.

6. TAHEREH M., YASUMASA T. Municipal solid waste management in Tehran: Changes during the last 5 years. Waste Management and Research, 34 (5), 449, 2016.

7. GUPTA N., YADAV K.K., KUMAR V. A review on current status of municipal solid waste management in India. Journal of Environmental Sciences, 37, 206, 2015.

8. YUAN H., WANG L., SU F., HU G. Urban solid waste management in Chongqing: Challenges and opportunities. Waste Management, 26 (9), 1052, 2006.

9. JIN J.J., WANG Z.S., RAN S.H. Solid waste management in Macao: Practices and challenges. Waste Management, 26 (9), 1045, 2006.

10. BAI R., SUTANTO M. The practice and challenges of solid waste management in Singapore. Waste Management, 22 (5), 557, 2002.

11. TIMILSINA B.P. Public and private sector involvement in municipal solid waste management: an overview of strategy, policy and practices. A Journal of the Environment, 6, 68, 2001.

12. SUDHAKAR Y., NT S. Assessment of alternative disposal methods to reduce greenhouse gas emissions from municipal solid waste in India. Waste Management and Research, 34 (6), 553, 2016.

13. PAN AMERICAN HEALTH ORGANIZATION (PAHO). Diagnosis of municipal solid waste management in Latin America and the Caribbean. Serie Ambiental, No. 18, 1998.

14. FUNARI V., MEISEL T., BRAGA R. The potential impact of municipal solid waste incinerators ashes on the anthropogenic osmium budget. Science of The Total Environment, 541, 1549, 2016.

15. KAWAI K., TASAKI T. Revisiting estimates of municipal solid waste generation per capita and their reliability. Journal of Material Cycles Waste Management, 18 (1), 1, 2016.

16. DAI Y.C., GORDON M.P.R., YE J.Y., XU D.Y., LIN Z.Y., ROBINSON N.K.L., WOODARD R., HARDER M.K. Why doorstepping can increase household waste recycling. Resources, Conservation and Recycling, 102, 9, 2015.

17. TIAN H.Z., GAO J.J., LU L., ZHAO D., CHENG K., QIU P.P. Temporal trends and spatial variation characteristics of hazardous air pollutant emission inventory from municipal solid waste incineration in China. Environmental Science and Technology, 46 (18), 10364, 2012.

18. VERGARA S.E., TCHOBANOGLOUS G. Municipal solid waste and the environment: a global perspective. Annual Review of Environment and Resources, 37, 277, 2012.

19. HOU D., AL-TABBAA A., GUTHRIE P., WATANABE $K$. Sustainable waste and materials management: national policy and global perspective. Environmental Science and Technology, 46, 2494, 2012.

20. THANH N.P., MATSUI Y. Compost potential from solid waste: toward sustainable agriculture and mitigation of global warming in Mekong Delta, Vietnam. In: Environmental Change and Agricultural Sustainability in the Mekong Delta. Springer Science Business Media, B.V., 2011.

21. EPA. Municipal solid waste generation, recycling, and disposal in the United States: Facts and figures for 2011. Washington D.C.: EPA; 2013. www.epa.gov/waste. 
22. REDDY K.R., HETTIARACHCHI H., GANGATHULASI J., BOGNER J.E. Geotechnical properties of municipal solid waste at different phases of biodegradation. Waste Management, 31 (11), 2275, 2011.

23. LOU X.F., NAIR J. The impact of landfilling and composting on greenhouse gas emissions: a review. Bioresource Technology, 100 (16), 12, 2009.

24. KOERNER R.G., EITH W.A. Drainage capability of fully degraded MSW with respect to various leachate collection and removal systems. Geotechnical Special Publication, 130, 4233, 2005.

25. SHEN L. Liquid depth study and stability analysis of municipal solid waste landfill. M.S. thesis, Zhejiang University, Zhejiang, China, 2011 [In Chinese].

26. MERRY S.M., KAVAZANJIAN JR. E., FRITZ W.U. Reconnaissance of the July 10, 2000, Payatas landfill failure. Journal of Performance of Constructed Facilities, 19 (2), 100, 2005.

27. CAICEDO B., GIRALDO E., YAMIN L. The landslide of Dona Juana Landfill in Bogota. A case study. Proceedings of the fourth international congress on environmental geotechnics ( $4^{\text {th }}$ ICEG), Rio de Janeiro, Brazil, 11, 2002.

28. BLIGHT, G. Slope failures in municipal solid waste dumps and landfills: a review. Waste Management and Research, 26 (5), 448, 2008.

29. IBRAHIM M.I.M., MOHAMED N.A.E.M. Towards sustainable management of solid waste in Egypt. Procedia Environmental Sciences, 34, 336, 2016.

30. GU B.X., JIANG S.Q., WANG H.K., WANG Z.B., JIA R.F., YANG J., HE S., CHENG R. Characterization, quantification and management of China's municipal solid waste in spatiotemporal distributions: A review. Waste Management, 61, 67, 2017.

31. GU B., ZHU W., WANG H., ZHANG R., LIU M., CHEN Y., WU Y., YANG X., HE S., CHENG R., YANG J., BI J. Household hazardous waste quantification, characterization and management in China's cities: a case study of Suzhou. Waste Management, 34 (11), 2414, 2014.

32. SAIDAN M.N., DRAIS A.A., AL-MANASEER E. Solid waste composition analysis and recycling evaluation: Zaatari Syrian Refugees Camp, Jordan. Waste Management, 61, 58, 2017.

33. MINISTRY OF MUNICIPAL AFFAIRS. Development of a National Strategy to Improve the Municipal Solid Waste Management Sector in the Hashemite Kingdom of Jordan. Amman, Jordan, 2015.

34. ZHOU H., MENG A.H., LONG Y.Q., LI Q.H., ZHANG Y.G. Classification and comparison of municipal solid waste based on thermochemical characteristics. Journal of the Air \& Management Association, 64 (5), 597, 2014.

35. ASSAMOI B., LAWRYSHYN Y. The environmental comparison of landfilling vs. incineration of MSW accounting for waste diversion. Waste Management, 32 (5), 1019,2012

36. GÓMEZ G., MENESES M., BALLINAS L., CASTELLS F. Seasonal characterization of municipal solid waste (MSW) in the city of Chihuahua, Mexico. Waste Management, 29 (7), 2018, 2009

37. LI Z.S., YANG L., QU X.Y., SU Y.M. Municipal solid waste management in Beijing City. Waste Management, 29 (9), 2596, 2009

38. FRÉSCA F.R.C. Analysis of Municipal Solid Waste Generation in São Carlos, SP, Considering Its Physical Characterization Master Dissertation. University of São Paulo, São Carlos, SP, Brazil, 2007 [In Portuguese].

39. GIDARAKOS E., HAVAS G., NTZAMILIS P. Municipal solid waste composition determination supporting the integrated solid waste management system in the island of Crete. Waste Management, 26 (6), 668, 2006.

40. BLIGHT G. Landfills-yesterday, today and tomorrow. Waste: A Handbook for Management, 469, 2011.

41. YANG R., XU Z.G., CHAI J.R., QIN Y., LI Y.L. Permeability test and slope stability analysis of municipal solid waste (MSW) in Jiangcungou Landfill, Shaanxi, China. Journal of the Air and Management Association, 66 (7), 655, 2016

42. MACHADO S.L., KARIMPOUR-FARD M, SHARIATMADARI N., CARVALHO M.F., DO NASCIMENTO J.C.F. Evaluation of the geotechnical properties of MSW in two Brazilian landfills. Waste Management, 30 (12), 2579, 2010.

43. GAO W., CHEN Y.M., ZHAN L.T., BIAN X.C. Engineering properties for high kitchen waste content municipal solid waste. Journal of Rock Mechanics and Geotechnical Engineering, 7 (6), 646, 2015.

44. POKHREL D., VIRARAGHAVAN T. Municipal solid waste management in Nepal: practices and challenges. Waste Management, 25 (5), 555, 2005.

45. REDDY K.R., HETTIARACHCHI H., PARAKALLA N.S., GANGATHULASI J. Geotechnical properties of fresh municipal solid waste at orchard hills landfill, USA. Waste Management, 29 (2), 952, 2009.

46. HULL R.M., KROGMANN U., STROM P.F. Composition and characteristics of excavated materials from a New Jersey landfill. Journal of Environmental Engineering, 131 (3), 479, 2005.

47. SAINT-FORT R. Assessing sanitary landfill stabilization using winter and summer waste streams in simulated landfill cells. Journal of Environmental Science and Health Part A, 37 (2), 237, 2002.

48. ZHOU H., MENG A.H., LONG Y.Q., LI Q.H., ZHANG Y.G. An overview of characteristics of municipal solid waste fuel in China: physical, chemical composition and heating value. Renewable and Sustainable Energy Reviews, 36, 107, 2014

49. WANG H., WANG C.M. Municipal solid waste management in Beijing: Characteristics and challenges. Waste Management and Research, 31 (1), 67, 2012.

50. YI S., YOO K.Y., HANAKI K. Characteristics of MSW and heat energy recovery between residential and commercial areas in Seoul. Waste Management, 31 (3), 595, 2011.

51. BOER D.E, JEDRCZAK A., KOWALSKI Z., KULCZYCKA J., SZPADT R. A review of municipal solid waste composition and quantities in Poland. Waste Management, 30 (3), 369, 2010.

52. PULAT H.F., YUKSELEN-AKSOY Y. Compaction behavior of synthetic and natural MSW samples in different compositions. Waste Management and Research, 31 (12), 1255, 2013.

53. BAREITHER C., BENSON C., EDIL T. Effects of waste composition and decomposition on the shear strength of municipal solid waste. Journal of Geotechnical and Geoenvironmental Engineering, 138 (10), 1161, 2012.

54. BAREITHER C., BENSON C., EDIL T. Compression behavior of municipal solid waste: immediate compression. Journal of Geotechnical and Geoenvironmental Engineering, 138 (9), 1047, 2012.

55. BABU G.S., LAKSHMIKANTHAN P., SANTHOSH, L. G. Shear strength characteristics of mechanically biologically treated municipal solid waste (MBT-MSW) from Bangalore. Waste Management, 39, 63, 2015. 
56. CASTELLI F., MAUGERI M. Mechanical properties of municipal solid waste by SDMT. Waste Management, 34 (2), 256, 2014

57. ZORNBERG J.G., JERNIGAN B.L., SANGLERAT T.R., COOLEY B.H. Retention of free liquids in landfills undergoing vertical expansion. Journal of Geotechnical and Geoenvironmental Engineering, 125 (7), 583, 1999.

58. ZEKKOS D., ATHANASOPOULOS G.A., BRAY J.D., GRIZI A., THEODORATOS A. Large-scale direct shear testing of municipal solid waste. Waste Management, 30 (8-9), 1544, 2010.

59. MINISTRY OF HOUSING AND URBAN-RURAL DEVELOPMENT OF THE PEOPLE'S REPUBLIC OF CHINA. Technical code for geo-technical engineering of municipal solid waste sanitary landfill. Construction Industry Press, Beijing, China, CJJ176, 2012 [In Chinese].

60. FENG S.J., GAO K.W., CHEN Y.X., LI Y., ZHANG L.M. CHEN H.X. Geotechnical properties of municipal solid waste at Laogang Landfill, China. Waste Management, 63, 354, 2017.

61. YU L., FRANCISCO B., JESÚS C. Variations of waste unit weight during mechanical and degradation processes at landfills. Waste Management and Research, 29 (12), 1303, 2017.

62. CHEN Y.M., KE H. Engineering characteristics of municipal solid wastes and geotechnical problems of landfills. Engineering Mechanics, 22, 119, 2005 [In Chinese].

63. LI M.Y., JAE H.K., XU Q.Y. Review about hydraulic conductivity of landfilled waste. Environmental Engineering, (8), 80, 2014 [In Chinese].

64. JANG Y.S., KIM Y.W., LEE S.I. Hydraulic properties and leachate level analysis of Kimpo metropolitan landfill, Korea. Waste Management, 22 (3), 261, 2002.

65. DURMUSOGLU E., SANCHEZ I.M., CORAPCIOGLU M.Y. Permeability and compression characteristics of municipal solid waste samples. Environmental Geology, 50, 773, 2006.
66. OLIVIER F., GOURC J.P. Hydro-mechanical behavior of municipal solid waste subject to leachate recirculation in a large-scale compression reactor cell. Waste Management, 27 (1), 44, 2007.

67. HOSSAIN M.S., PENMETHSA K.K., HOYOS L. Permeability of municipal solid waste in bioreactor landfill with degradation. Geotechnical and Geological Engineering, 27, 43, 2009.

68. REDDY K.R., HETTIARACHCHI H., PARAKALLA N., GANGATHULASI J. Hydraulic conductivity of MSW in landfills. Journal of Environmental Engineering, 135 (8), 677, 2009.

69. JIE Y.X., DANZENG D.Z., WEI Y.F. Study on the Permeability of Municipal Solid Waste. Geotechnical Engineering Technique, 19 (6), 307, 2005 [In Chinese].

70. WYSOCKI E., NABAVI T., DJAFARI S. The use of leachate recovery wells to evaluate municipal solid waste hydraulic characteristics at Fresh Kills Landfill. $8^{\text {th }}$ Annual Landfill Symp, 2003.

71. KOELSCH F., FRICKE K., MAHLER C., DAMANHURI E. Stability of landfills-the Bandung dumpsite disaster. Proceedings Sardinia, 2005.

72. STOLTZ G., GOURC J.P., OXARANGO L. Liquid and gas permeabilities of unsaturated municipal solid waste under compression. Journal of Contaminant Hydrology, 118 (1-2), 27, 2010.

73. KE H., RAN L., CHEN Y.M., FENG S.J. Study on MSW filtration experimentation and landfill hydrologic analysis. Chinese Journal of Geotechnical Engineering, 28 (5), 631, 2006 [In Chinese].

74. JAIN P., POWELL J., TOWNSEND T.G., REINHART D.R. Estimating the hydraulic conductivity of landfilled municipal solid waste using the borehole permeameter test. Journal of Environmental Engineering, 132 (6), 645, 2006.

75. WU H.Y., CHEN T., WANG H.T., LU W.J. et al. Field air permeability and hydraulic conductivity of landfilled municipal solid waste in China. Journal of Environmental Management, 98, 15, 2012. 
